\title{
EDITORIAL
}

\section{Scholarship and literacies in a digital age}

There is growing interest in the impact of digital technologies on meaning-making practices and identity in education, which has been explored via the related concepts of 'digital scholarship' and 'digital literacies'. However, to date, much published work in this area has been descriptive, identifying possibilities or promoting specific kinds of intervention. Far rarer is work that develops concepts, links to research outside of the field of learning technology or work that uses new data to challenge existing orthodoxies.

Substantial effort has been invested in developing and promoting digital literacy. It has been the focus of European projects (Martin and Grudziecki 2006); became the cornerstone for substantial investment in the United Kingdom by the JISC (Beetham, McGill and Littlejohn 2009), leading to 12 projects being funded ${ }^{1}$; became the focus for an The Economic and Social Research Council (ESRC) seminar series, ${ }^{2}$ which led to a book being produced (Goodfellow and Lea 2013); and has stimulated international networks such as the UK-Canadian programme of workshops on 'New Media, New Literacies and New Forms of Learning, ${ }^{3}$

Meanwhile, new forms of scholarship have attracted considerable interest at policy levels. Here, close connections are proposed between ideals of openness and digital mediation, particularly of research outputs. The European Union has communicated its intent to require research outputs (and potentially data) to be made 'open' (European Commission 2012), primarily in digital form. In the United Kingdom, the Finch Working Group (2012) recommended a wholesale move to 'Gold' open access in response to the 'widespread perception, in the UK and across the world, that the full benefits of advances in technologies and services in the online environment have yet to be realized' (p. 4) - recommendations that were endorsed by the UK government that will soon be linked to funding requirements, even though the 'complex ecology with many different agents and stakeholders' (p. 13) in which this intervention is located has not been well described nor understood. Indeed, such policies are often framed as interventions, framed unproblematically in technicist terms of efficiency and markets. The concepts of 'digital scholarship' or 'open scholarship' in general have tended to refer to the impact of digital technologies on academics' practices, as with the Open University digital scholarship research strand, ${ }^{4}$ or else refer to data management, as with the Royal Society's Open Science report. ${ }^{5}$

By thus focusing largely on 'access' in its technical dimension, such accounts fail to explore what might happen before or after these moments of information access, or what these changes might mean to the various people involved.

Work that has looked at changes has been undertaken within academic practice; this frequently draws on Boyers' four forms of scholarship (e.g. Pearce et al. 2012), seeking to understand scholarship in a digital age in terms of discovery, integration, application and teaching. Much of this writing, however, relies on analogies to 


\section{Editorial}

commercial arenas such as music publishing, and relatively little is grounded in empirical data (although there are some notable exceptions, such as recent work by Esposito 2013), and there is much focus on potentials or advocacy rather than critical explorations of such developments.

Several problems can be observed with these developments. Firstly, there is considerable fragmentation; research efforts often remain disparate and unconnected. This is a missed opportunity, and it is important to begin drawing these separate threads together in order to consolidate our understanding of the issues involved. Secondly, it is important to broaden the kind of works being undertaken in this area beyond the technical, instrumental orientation that has tended to be most visible in research and policy (cf. Friesen 2009, 7). Thirdly, a better understanding needs to be developed of the various ways in which these proposals and developments relate to the established practices of learners, academics and others. Finally, many of the discussions remain conceptually under-developed. The development of models such as the pyramid model of digital literacies developed by Sharpe and Beetham (2010) has helped ground conversations in common terminology, but there remains a lack of conceptual clarity that results in ambiguity and misunderstanding. We need better accounts of how these contemporary discussions relate to wider concerns about access, power, learning, participation and the knowledge economy.

The papers in this special issue help to address these shortcomings in the field. Broadly, they can be categorised into two groups. The first focuses on the practices of digital literacy, drawing from research in areas such as New Literacy Studies and exploring how established concepts and findings relate to digitally mediated contexts of learning. The second group addresses the relationship between forms of scholarship, including teaching, and openness.

Gourlay, Hamilton and Lea open the papers that address literacies by exploring the relationships - and in some cases the lack of a relationship - between fields that might reasonably be expected to contribute to these debates. Reviewing debates and developments that have taken place in New Literacy Studies, the authors reveal a tendency to revert to common sense usage of terms such as 'literacy', losing sight of the hard-won theoretical development of these concepts, or even misappropriating the terms in ways inconsistent with their previous usage. The consequent risk of 'talking past each other' is a salutary reminder of the importance of grounding contemporary research in clearly articulated positions, making them amenable to critique and development.

From this framing of issues, Hinrichsen and Coombs move forward by doing precisely this: grounding discussions of curriculum issues related to digital literacies in an articulation and development of a well-established model of critical literacy, the Four Resources (or reader roles) model. This helped resist 'a drift towards functional approaches (what tools and what skills) and incoherent variability', which is arguably characteristic of much of the descriptive research undertaken in this area. This has important implications for curriculum design, which are elaborated for each of the roles, providing a framework for future practice.

Bhatt and de Roock show how these wider debates and considerations play out in specific situations, focusing on the analysis of digital literacy events in college and school. The careful analysis of learners' practices draws on sociomaterial perspectives - a perspective shared by several of the papers in this special issue - in order to move away from generic, taxonomic accounts of digital literacies as decontextualised 
'skills'. Instead, it reframes successful digital literacy events as complex assemblages that bring together people and things. This constitutes a marked reframing of what 'counts' as digital literacy, with important implications for how researchers working in this area might frame the unit of analysis for their work.

The paper by Goodfellow opens the second group of contributions in this issue with a sober second look at access to scholarship more generally. Access, of course, involves much more than an uninterrupted flow of data to a given end-user; it raises questions of quality and orientation in terms of potential audience, (non-)specialised readership and membership to communities of knowledge and practice. In these terms, Goodfellow argues that access can readily appear as a zero-sum game or a trade-off between specialised precision on the one hand, and a diluted generality or inclusivity on the other. Addressing these and other potential trade-offs presents a valuable opportunity to revisit questions about the public mission of the university and responsibility of its members.

Knox and Bayne consider open forms of engagement - specifically in the context of a Coursera MOOC - from the perspective of sociomateriality. Such a perspective, they show, presents an opportunity for re-conceiving digital literacies not as a set of pre-defined skills or a set of representational possibilities and combinations but in terms of something that has always been close to its centre - from its textual to its digital incarnations. Digital literacies are seen here as complex enactments specific to given communicative and inscriptive technologies; performances in which human and material actors are multiply and inextricably entangled.

Costa, rounding out the contributions to this group and to the special issue, examines questions of access and scholarly practice from the perspective of Bourdieu's notions of habitus, field, and social and cultural capital. This paper looks to the everyday sites and dispositions of digital scholars to understand their involvement in various academic networks and virtual communities. Echoing Goodfellow's concerns about access, Costa's findings show that the norms and expectations of these scholars' respective professional communities - now more a 'virtual' rather than an 'invisible' college - are of paramount importance. However, Costa's findings suggest that as these expectations continue to be ever more grounded in open and accessible practice, the outlook for realising openness, not just formally but also substantively, is promising.

Taken together, these papers provide a range of perspectives on this fast-moving area of engagement with technology, reminding us of the urgent need for sustained critical and theorised work in this field.

\section{Notes}

1. http://www.jisc.ac.uk/developingdigitalliteracies

2. http://literacyinthedigitaluniversity.blogspot.co.uk/

3. http://blogs.ubc.ca/newliteracies/

4. http://www8.open.ac.uk/iet/main/research-scholarship/our-research-scholarshipprogrammes/digital-scholarship

5. http://royalsociety.org/policy/projects/science-public-enterprise/report/

\section{References}

Beetham, H., McGill, L. \& Littlejohn, A. (2009) Thriving in the 21st Century: Learning Literacies for the Digital Age (LLiDA project), Project report, [online] Available at: http:// www.jisc.ac.uk/media/documents/projects/lidareportjune2009.pdf 


\section{Editorial}

Esposito, A. (2013) 'Neither digital or open. Just researchers. Views on digital/open scholarship practices in an Italian university', First Monday, vol. 18, no. 1, [online] Available at: http://journals.uic.edu/ojs/index.php/fm/article/view/3881/3404

European Commission (2012) Towards Better Access to Scientific Information: Boosting the Benefits of Public Investments in Research. COM(2012) 401 final, European Commission, Brussels, [online] Available at: http://ec.europa.eu/research/science-society/document_ library/pdf_06/era-communication-towards-better-access-to-scientific-information_en.pdf

Finch Working Group (2012) Report of the Working Group on Expanding Access to Published Research Findings, [online] Available at: http://www.researchinfonet.org/wp-content/ uploads/2012/06/Finch-Group-report-FINAL-VERSION.pdf

Friesen, N. (2009) Rethinking E-Learning Research, Peter Lang, New York.

Goodfellow, R. \& Lea, M. (2013) Literacy in the Digital University: Critical Perspectives on Learning, Scholarship and Technology, Routledge, London.

Martin, A. \& Grudziecki, J. (2006) 'DigEuLit: concepts and tools for digital literacy development', Innovation in Teaching And Learning in Information and Computer Sciences, vol. 5, no. 4, pp. 249-267.

Pearce, N., et al. (2012) 'Digital scholarship considered: how new technologies could transform academic work', In Education, vol. 16, no. 1, [online] Available at: http://ineducation.ca/ ineducation/article/view/44/509

Royal Society. (2012) Science as an Open Enterprise. The Royal Society Science Policy Centre report 02/12, Royal Society, London, [online] Available at: http://royalsociety.org/policy/ projects/science-public-enterprise/report/

Sharpe, R. \& Beetham, H. (2010) 'Understanding students' uses of technology for learning: towards creative appropriation', in Rethinking Learning for the Digital Age: How Learners Shape their Experiences, eds. R. Sharpe, H. Beetham \& S. de Freitas, RoutledgeFalmer, London, pp. 85-99.

Norm Friesen

Boise State University, Idaho

Lesley Gourlay

Institute of Education

University of London

$\mathrm{UK}$

Martin Oliver

Institute of Education

University of London

UK 